\title{
Advanced Care Planning: a Bibliographic Review from the Perspective of Social Work in Health Care
}

\section{Rodriguez JMJ1* and Gomez MP²}

${ }^{1}$ Faculty of Social Work, University of Granada, Spain

${ }^{2}$ Faculty of Social Work of the Complutense, University of Madrid, Spain

*Corresponding author: Jose Manuel Jimenez Rodriguez, Social Worker in the Andalusian Health Service, Associate Professor at Faculty of Social Work, University of Granada, (Armilla) Granada, Spain, Tel: 958 840388/636174168; Email: jose.jimenez.rodriguez.sspa@juntadeandalucia.es

\section{Research Article}

Volume 3 Issue 2

Received Date: April 14, 2020

Published Date: May 07, 2020

DOI: $10.23880 /$ abca-16000119

\section{Abstract}

This study aims at identifying the role that Social Work in Health Care in the process of Advanced Care Planning (hereinafter ACP). For this purpose, a bibliographic review has been carried out whose population study was composed of scientific articles related to ACP, published between 1 Jan. 2009 and 1 Jan. 2019, related to the Social Work aria Health Care discipline. For the selection of articles, descriptors from Medical Subject Heading (MeSH) have been used. The search terms "Social Work" and "Advanced Care Planning" have been used in natural and controlled language. Boolean operators ("y" "and", in Spanish and English) have also been used. Regarding search platforms and databases, the following have been used: PubMed, Cochrane Library Plus, IME, CSIC, SCOPUS, OvidSPMEDLINE and Google Scholar. As to the results, 14,248 articles were located, from which 1,295 entered the review process of these, only 20 were selected as the rest did not adapt to the selection criteria. Looking at the year of publication, the scientific production for 2016 represented $27.2 \%$ of the total. Regarding the type of research, $45.4 \%$ were quantitative studies and $90.9 \%$ focused their attention on the attitude of Social Work professionals regarding the ACP. With regard to the categories of the reviewed articles, $45.4 \%$ referred to training in Social Work in Health Care on Advanced Care Planning ACP. That same percentage referred to the commitment of these professionals with ACP. The current study shows that Social Workers in Health Care have the aptitude and commitment necessary for Advanced Care Planning ACP. However, these professionals require more training. The paper also raises the issue that the topic of a dignified 'end of life' process needs to be present in syllabuses for grade and postgraduate education within the Social Work in Health Care discipline.

Keywords: Advance Care Planning; Bibliographic Review; End of Life; Social Work in Health Care

\section{Introduction}

Advanced Care Planning (hereinafter ACP) refers to the communicative process, matured, free and conscious, between the patient and the health professional, where the former expresses in writing his or her health preferences so that they are taken into account [1]; that is, once the illness has advanced and, with it, the ability to freely communicate disappears. The term 'living will' exceeds the mere administrative act. In addition to the patients' health wishes, it incorporates their history of values and beliefs, without the limitations of lex artis [2-4]. This enhances the patient's decision-making capacity and circumscribes professionals in Social Work in Health Care in their assistance act, favouring 
a limitation of therapeutic effort and the right to clinical selfdetermination [5].

In Spain, Advanced Care Planning ACP is a health benefit regulated at the legal level and incorporated into the portfolio of services offered by the different health administrations. The Law 41/2002, of November 14, sets the basic regulation for patient autonomy, rights and obligations regarding information and clinical documentation (article 11) [6]. It is a second generation right that any person may use at any time. Its offer and setting up requires prior knowledge and training, beyond neophyte acts, and also the ability to start the process itself.

The units of services in Social Workin Health Care can be an appropriate scenario from which to talk about ACP [7]. Social Workers in Health Care assume and develop professional roles compatible with this process: communicative abilities, active listening, advice, management, processing, among others. Warmth in professional Health Care is also fundamental [8]. These professionals are aware of regulations and their knowledge is in continuous recycling, a fact that allows them to integrate and adapt to Health Care services and procedures. In addition, empathic attitudes may enable, for instance, the channelling of emotional crises [9-11]. All these aspects emphasize the importance of Social Work in Health Care in relation to Advanced Care Planning ACP.

\section{Objectives}

The aim of this paper is to identify and describe the role that professionals in Social Work in Health Care play in Advanced Care Planning ACP by means of the analysis of bibliographic information on the topic.

\section{Material and Method}

The paper encompasses a bibliographic review with the following characteristics:

\section{Study Population}

The paper analyses scientific articles, published between January 1, 2009 and January 1, 2019, related to Advanced Care Planning ACP and their relation to the Social Work in Health Care discipline.

\section{Sample and sampling type}

Descriptors in Medical Subject Heading (MeSH) have been used for the selection of the sample of analysis. The terms "Social Work" and "Advanced Care Planning" were used in natural and controlled language. Boolean operators ("y" "and". in Spanish and English) were also used. For the selection, the following databases were used: PubMed, Cochrane Library Plus, IME, CSIC, SCOPUS, OvidSPMEDLINE and Google Scholar.

\section{Sample Selection Criteria}

Inclusion: This study includes all journal articles whose title contains the following keywords (in Spanish and English): Advance Care Planning, Social Work in Health Care and Social Assistance. The terms are related to each other and refer to the role, action models, type of interventions and decision-making of Social Workers in Health Care in relation to Advanced Care Planning ACP.

Exclusion: The study excludes those articles that do not have an abstract. It also excludes journal supplements. Also discarded are those articles whose title exclusively includes care at the end of life without reference to Social Work in Health Care. Likewise, articles not found in Open Access are excluded, just as those items that are duplicated in the selected databases.

\section{Type of analysis}

The type of analysis performed is descriptive (secondary). No computer software has been used for this analysis.

\section{Schedule}

\begin{tabular}{|c|c|c|c|c|c|c|}
\hline & January & February & March & April & May & 2019-June \\
\hline Research Approach & & & & & & \\
\hline Design \& presentation of preliminary research protocol & & & & & & \\
\hline Field work / Bibliographic search & & & & & & \\
\hline Analysis \& interpretation of resulting data & & & & & & \\
\hline Data discussion and conclusions & & & & & & \\
\hline Presentation of the final report & & & & & & \\
\hline Dissemination of results & & & & & & \\
\hline
\end{tabular}




\section{Limitations of the study}

Limitations are related to:

$>$ The existence or not of documents included in databases and journals lacking $\mathrm{OA}$.

$>$ The deficit in the number of specialized scientific publications on the subject itself.

$>$ The specificity of the selected theme.

$>$ The volume of scientific literature produced by Social Work in Health Care.

$>$ Possible biases of bibliographic reviews.

\section{Results}

Initially, 14,248 articles where located but only 1,295 entered the review process of these articles, 20 were finally selected for analysis, as the rest did not adapt to the selection criteria. Taking into consideration the year of publication, the scientific production for 2016 represented $27.2 \%$ of the total. Regarding the type of research, $45.4 \%$ were quantitative studies and $90.9 \%$ focused their attention on the attitude of Social Work professionals in Health Care in relation to Advanced Care Planning ACP. With regard to the categories of the reviewed articles, $45.4 \%$ referred to the training of Social Work professionals in Health Care on ACP. That same percentage referred to their commitment with ACP. Only $9.09 \%$ cite ACP research as a category (Figures 1-3) (Tables $1 \& 2$ ).

\begin{tabular}{|c|c|c|c|c|}
\hline Data Base & $\begin{array}{l}\text { Search } \\
\text { Period }\end{array}$ & $\begin{array}{c}\text { Findings \& } \\
\text { Results }\end{array}$ & Search Parameters $(*)$ & $\begin{array}{l}\text { Selected } \\
\text { Articles }\end{array}$ \\
\hline $\begin{array}{l}\text { COCHRANE } \\
\text { LIBRARY }\end{array}$ & $2009-2019$ & 896 & $\begin{array}{c}\text { Advanced search. Search terms included in the title or keywords } \\
\text { of the manuscript. }\end{array}$ & 0 \\
\hline EMBASE & $2009-2019$ & 143 & $\begin{array}{c}\text { Advanced search. Search terms included in the title or keywords } \\
\text { of the manuscript. }\end{array}$ & 8 \\
\hline $\begin{array}{c}\text { GOOGLE } \\
\text { ACADÉMICO }\end{array}$ & $2009-2019$ & 70 & $\begin{array}{c}\text { Advanced search. Search terms included in the title or keywords } \\
\text { of the manuscript. }\end{array}$ & 1 \\
\hline IME/ CSIC & 2009-2019 & $12.953(* *)$ & $\begin{array}{l}\text { Advanced search. Search terms included in the title or keywords } \\
\text { of the manuscript. }\end{array}$ & 0 \\
\hline $\begin{array}{l}\text { OVIDSPMEDLINE/ } \\
\text { CSIC }\end{array}$ & 2009-2019 & 0 & $\begin{array}{c}\text { Advanced search. Search terms included in the title or keywords } \\
\text { of the manuscript. }\end{array}$ & 0 \\
\hline PUBMED & $2009-2019$ & 186 & Advanced search. & 11 \\
\hline SCOPUS/ CSIC & $2009-2019$ & 0 & $\begin{array}{c}\text { Advanced search. Search terms included in the title or keywords } \\
\text { of the manuscript. }\end{array}$ & 0 \\
\hline
\end{tabular}

Source: Own elaboration based on the data obtained from the 2019 research.

Table 1: Bibliographic review according to selected databases \& established search parameters.

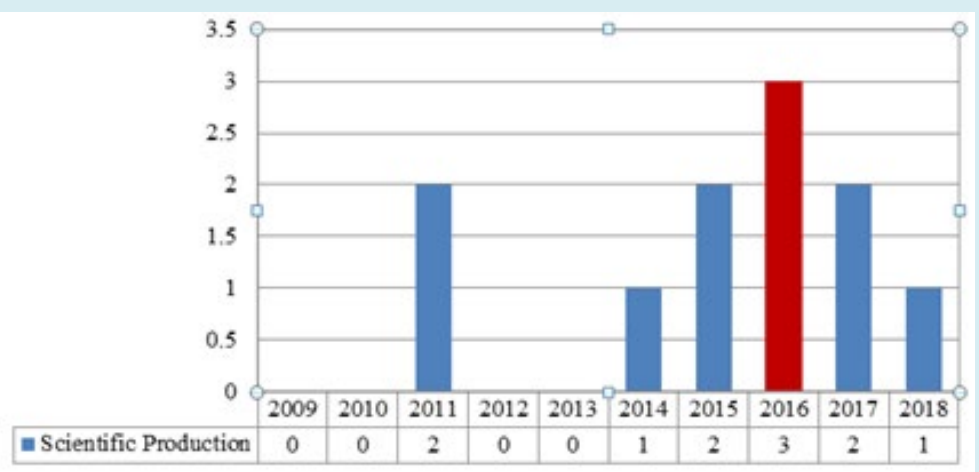

Source: Own elaboration based on the data obtained from the 2019 research.

Figure 1: Scientific production on Advanced Care Planning at the international level (2009-2019). 


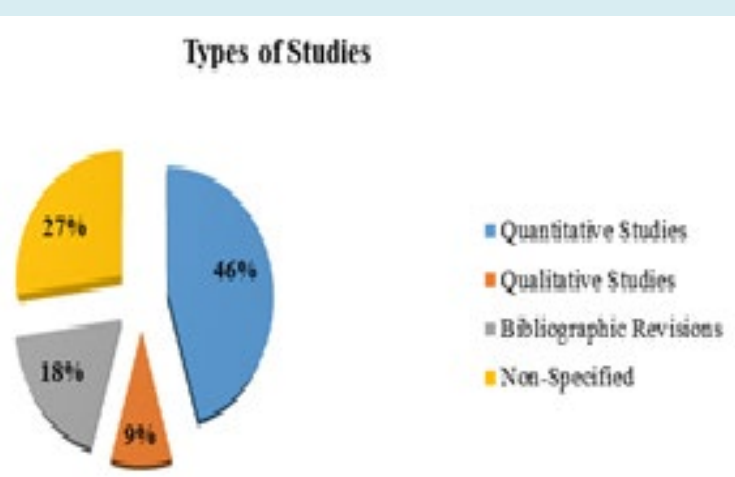

Source: Own elaboration based on the data obtained from the 2019 research. Figure 2: Type of research studies on ACP at international level (2009-2019).
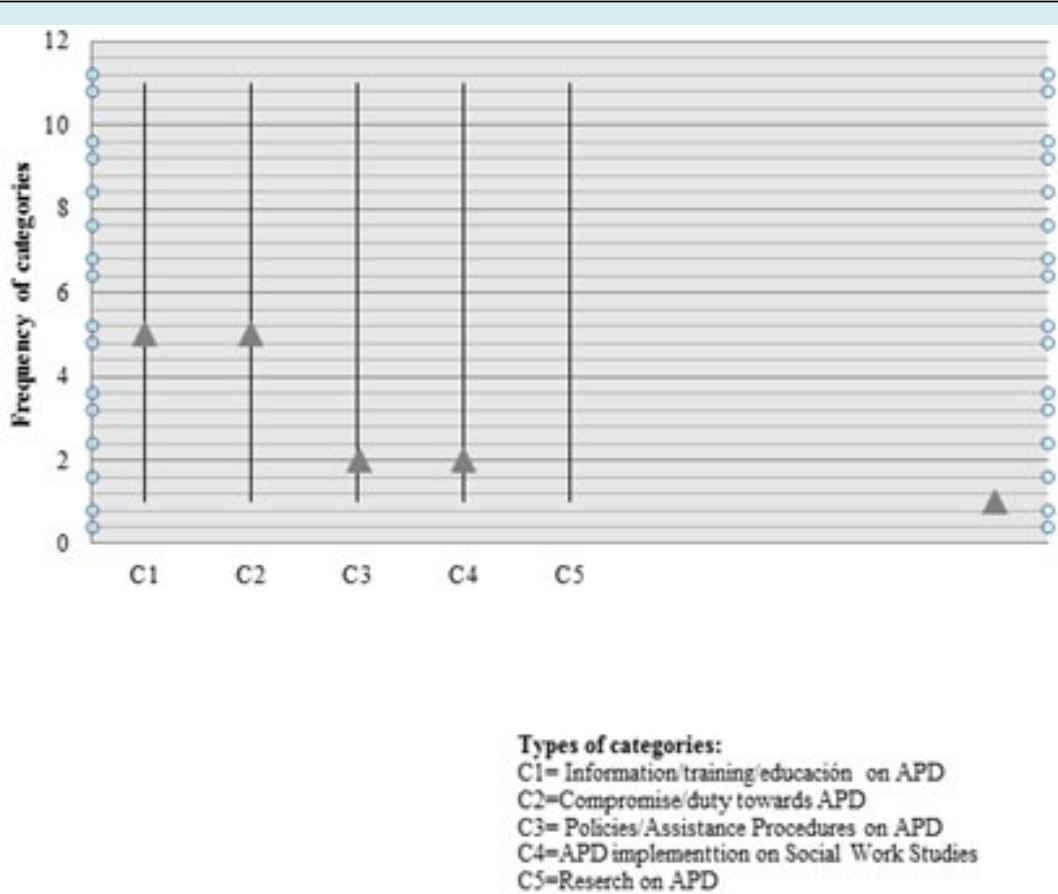

Source: Own elaboration based on the data obtained from the 2019 research. Figure 3: Frequency of categories related to ACP and Social Work in Health Care.

\begin{tabular}{|c|c|c|c|c|}
\hline Author & Type of Study & $\begin{array}{c}\text { Analytical } \\
\text { Variables }\end{array}$ & $\begin{array}{c}\text { Year of } \\
\text { Publication }\end{array}$ & Main Scientific Contributions \\
\hline Nedjat FR, et al. [12] & $\begin{array}{c}\text { Qualitative study. N } \\
32 \text { (Latino population). } \\
\text { Instrument for data } \\
\text { collection: use of interview. } \\
\text { Comparative method. }\end{array}$ & Knowledge & 2018 & $\begin{array}{c}\text { The authors consider necessary to adapt } \\
\text { the communication in professional- } \\
\text { patient relationships in order to } \\
\text { improve ACP understanding. They also } \\
\text { recommend increased information about } \\
\text { ACP process. }\end{array}$ \\
\hline
\end{tabular}




\begin{tabular}{|c|c|c|c|c|}
\hline Wang CW, et al. [13] & $\begin{array}{c}\text { Bibliographic review } \\
\text { Search parameters: ACP } \\
\text { and Social Work. N = } 31\end{array}$ & $\begin{array}{l}\text { Attitude: } \\
\text { professional } \\
\text { responsibility }\end{array}$ & 2017 & $\begin{array}{l}\text { Their findings indicate that there is } \\
\text { consensus among social health workers, } \\
\text { regarding their duty and responsibility in } \\
\text { ACP, and the need to move forward in its } \\
\text { development. Likewise, the study shows } \\
\text { that social workers in health care play } \\
\text { an important role in ACP promotion and } \\
\text { implementation through concrete actions. } \\
\text { Finally, the authors consider the need } \\
\text { for additional studies that complement } \\
\text { their work with aspects related to impact } \\
\text { such as diverse pathologies and different } \\
\text { socio-cultural contexts. }\end{array}$ \\
\hline Stein GL, et al. [14] & $\begin{array}{c}\text { Quantitative study } N= \\
\text { 641. Subsample consisting } \\
\text { of health social workers } \\
\text { whose } N=456 . \text { Instrument } \\
\text { for data collection: use of } \\
\text { the survey. }\end{array}$ & $\begin{array}{l}\text { Attitude: } \\
\text { Information }\end{array}$ & 2017 & $\begin{array}{l}\text { The authors indicate that social workers } \\
\text { in health care ( } 96 \% \text { of the cases) talk with } \\
\text { patients and families about ACP. Most of } \\
\text { these professionals discuss ACP, and give } \\
\text { their options on ACP. However, this study } \\
\text { may be bias because of the unit-service to } \\
\text { which it belongs. Similarly, social workers } \\
\text { in health care are involved in facilitating, } \\
\text { directing and documenting ACP. Hence, } \\
\text { the authors urge health administrations } \\
\text { to carry out policies and programs that } \\
\text { incorporate the vital contributions of } \\
\text { social workers in health care to ACP. }\end{array}$ \\
\hline Peres J, et al. [15] & Unspecified & $\begin{array}{c}\text { Attitude: } \\
\text { Professional } \\
\text { responsibility }\end{array}$ & 2016 & $\begin{array}{l}\text { The author reflects on the importance } \\
\text { and duty of social workers in health } \\
\text { care to offer comprehensive care to } \\
\text { patients and families requesting ACP, } \\
\text { where professionals need to follow a } \\
\text { biopsychosocial model. Likewise, the } \\
\text { author states that the quality of care will } \\
\text { improve when the state addresses the } \\
\text { systemic problems surrounding ACP, } \\
\text { that is, policies regarding financing and } \\
\text { service provision. }\end{array}$ \\
\hline Kwon SA, et al. [16] & $\begin{array}{l}\text { Quantitative study } \mathrm{N}= \\
\text { 246. Instrument for data } \\
\text { collection: use of the } \\
\text { survey. }\end{array}$ & $\begin{array}{l}\text { Attitude: } \\
\text { Information }\end{array}$ & 2016 & $\begin{array}{l}\text { This study indicates that } 73 \% \text { of } \\
\text { participants do not report on living-wills. } \\
\text { Social workers in health care emphasize } \\
\text { self-determination as a professional } \\
\text { value. These professionals have a } \\
\text { positive attitude towards ACP and feel } \\
\text { comfortable talking about issues related } \\
\text { to 'end-of-life'. The results of this study } \\
\text { show the need to implement the ACP } \\
\text { and 'end-of-life' policies in social work } \\
\text { studies. }\end{array}$ \\
\hline
\end{tabular}




\begin{tabular}{|c|c|c|c|c|}
\hline $\begin{array}{c}\text { Francoeur RB, et al. } \\
{[17]}\end{array}$ & Unspecified & $\begin{array}{l}\text { Attitude: } \\
\text { Professional } \\
\text { responsibility }\end{array}$ & 2016 & $\begin{array}{l}\text { In this study, the authors confirm the } \\
\text { ability of social workers in health care } \\
\text { to intervene in populations of diverse } \\
\text { cultures and offer 'spiritual support' } \\
\text { adjusted to the beliefs of individuals. } \\
\text { These authors consider that it is the } \\
\text { responsibility of social workers in } \\
\text { health care to provide this spiritual care, } \\
\text { becoming aware of the ethical dilemmas } \\
\text { that may appear with other professionals } \\
\text { during the development of their } \\
\text { interventions. For these authors, social } \\
\text { work education must address humanist } \\
\text { and existential postulates, religious and } \\
\text { spiritual beyond traditional approaches. } \\
\text { Social workers in health care must } \\
\text { commit themselves to attending to the } \\
\text { different theological perspectives present } \\
\text { in grieving processes and ACP. }\end{array}$ \\
\hline Arthur DP, et al. [18] & Unspecified & Attitude. & 2015 & $\begin{array}{l}\text { This study emphasizes the importance } \\
\text { of education in issues related to sexual } \\
\text { orientation and trends and preferences } \\
\text { of ACP applicants as a way to provide } \\
\text { comprehensive care. The author wants } \\
\text { his work to serve as a tool to be used } \\
\text { in postgraduate studies and medical } \\
\text { professions as well as social work. }\end{array}$ \\
\hline $\begin{array}{c}\text { Jiménez JMR, et al. } \\
{[19,20]}\end{array}$ & Quantitative Study N=186. & Attitude & 2015 & $\begin{array}{l}\text { In this study, the author demonstrates } \\
\text { that social workers in Primary Healthcare } \\
\text { present an adequate profile to start ACP } \\
\text { processes with patients. Their knowledge } \\
\text { and attitudes can contribute to ACP } \\
\text { development and promotion. }\end{array}$ \\
\hline $\begin{array}{c}\text { Kwon SA, Alper J, et } \\
\text { al. [21] }\end{array}$ & $\begin{array}{l}\text { Quantitative study } \mathrm{N}= \\
102 \text { Instrument for data } \\
\text { collection: use of the } \\
\text { survey. }\end{array}$ & Attitude & 2014 & $\begin{array}{l}\text { This study shows that Social Work } \\
\text { students have a positive attitude towards } \\
\text { ACP. Participants in the study show } \\
\text { preferences for pain relief treatment, } \\
\text { (comfortable) communication about } \\
\text { 'end-of-life', self-determination and } \\
\text { understanding of the conflicts arising } \\
\text { from this right. The results of this study } \\
\text { raise the need, on the part of society, to } \\
\text { recognize the preferences of individuals } \\
\text { regarding 'end-of-life' care and higher } \\
\text { levels of comfort to discuss death. } \\
\text { Finally, the study considers that social } \\
\text { workers in health care should increase } \\
\text { their commitment to maintaining ethical } \\
\text { principles such as the one related to the } \\
\text { right to free decision. }\end{array}$ \\
\hline
\end{tabular}




\begin{tabular}{|c|c|c|c|c|}
\hline $\begin{array}{c}\text { Gutheil IA, et al. } \\
\text { [22] }\end{array}$ & $\begin{array}{l}\text { Quantitative (cross- } \\
\text { sectional) study. } \mathrm{N}= \\
\text { 844. Instrument for data } \\
\text { collection: not specified. }\end{array}$ & Attitude & 2011 & $\begin{array}{l}\text { With this study, the authors inform } \\
\text { attitudes of social workers in health care } \\
\text { towards ACP. They stress the need to } \\
\text { bridge the gap of clinical supremacy in } \\
\text { doctor-patient relationships, and signal } \\
\text { the need to talk about the impact of ACP } \\
\text { and of social workers' experience in the } \\
\text { profession. }\end{array}$ \\
\hline $\begin{array}{c}\text { Bomba PA, et al. } \\
{[23]}\end{array}$ & $\begin{array}{l}\text { Pilot study Literature } \\
\text { review }\end{array}$ & $\begin{array}{l}\text { Attitude (in } \\
\text { terms of role). }\end{array}$ & 2011 & $\begin{array}{l}\text { For the authors of this study, social } \\
\text { workers in health care are a key piece } \\
\text { in medical care. These professionals } \\
\text { work with patients, family members, } \\
\text { health professionals, and other agents } \\
\text { of the health system mediating in } \\
\text { communication, conflict resolution and } \\
\text { decision-making, among others. In the } \\
\text { same way, the study establishes a series } \\
\text { of recommendations to social workers } \\
\text { in health care that include research and } \\
\text { participation in 'end-of-life'. }\end{array}$ \\
\hline
\end{tabular}

Table 2: Analysis of the literature Review.

\section{Discussion}

ACP is a communicative process in which Social Work in Health Care is directly or indirectly involved. According to the studies reviewed, it can be said that, social workers in health care talk to patients and/or their families about ACP. It is also evident that these professionals have the necessary knowledge to start a dialogue with those involved in the granting the declaration of 'living wills' [24]. Authors like M.E. Baker believe that social workers in health care have the knowledge and the right attitude to start ACP processes. It is clear from his study that the knowledge of these professionals is directly linked to their professional experience, which implies that the greater the number of years dedicated to social work in health care, the greater their knowledge [25]. In a second study, the author demonstrates that social health workers talk more about ACP with stakeholders than doctors and nurses [13]. On his part, Jimenez JM, et al. [7] points out those health social workers have a higher knowledge of how to handle the patients' wishes as well as an adequate ACP attitude. However, in spite of having greater knowledge than other health professionals such as doctors and nurses, they do not initiate dialogue or ACP processes. For other authors such as Wang CW, et al. [26] and collaborators social workers in health care do not have enough information or training to start ACP processes. For these authors, their educational limits represent an important barrier for these professionals. Stein GL, et al. [14] and collaborators also indicate in that social workers in health care inform and initiate the dialogue about ACP with patients, as well as getting involved to facilitate and direct such process. Again, this work may be conditioned by the service-unit to which they are attached. The duties of social workers in health care and their commitment as social work professionals are linked to their ability to offer support. This support is extended in its implications on issues related to ACP and also to grieving processes [17]. Here the fundamentals and ethical considerations are vital, and although these considerations are contemplated in the deontological codes, it is necessary to strengthen the commitments for the maintenance of ethical principles such as the right to free decisions [21]. Jiménez points out those social workers in health care do not present deontological resistance, nor are they influenced by the system of values and beliefs in matters related to ACP. Nevertheless, none of the professionals analysed starts the ACP process [20]. To conclude, the role of social workers in health care as mediators and guides of communication spaces is evidently essential (for instance, in conflict resolution), so that greater familiarity with ACP is necessary, particularly with regards to its development and dissemination at a scientific level [23].

\section{Conclusion}

The bibliographic review performed in this study highlights the shortage of published research related to ACP and Social Work, which are emerging with great force since 2011. ACP is constituted as a right, regulated by the Spanish health system. This is so because of national regulation, not specific to this matter, and its different regional regulations. Incorporated in a portfolio of services under the pseudonym of living will, ACP complies with citizenship rights. In the exercise of its sanitary competences, ACP guarantees the 
right to clinical self-determination. Health professionals must respond to this request as well as to the demands expressed by the patients interested in starting ACP processes, granting their declaration of living will. From the performed analysis, the main conclusion reached is that Social Workers in Health Care are the perfect figures to initiate a dialogue on ACP. These professionals present a competence profile adjusted to the requirements of this process [27]. Their functions, related to giving information, advice, assessment, and providing help in administrative processing, make them a key piece for the development in ACP. Hence, they must design and channel action protocols that redirect these benefits to the Social Work units in Health Care [28,29].

It is necessary that the different state health administrations provide additional competences in the form of specific training to these professionals. In order to achieve this goal, it is necessary to implement ACP training at the level of university curricula. It is also fundamental to enforce regulated training at the level of grade and postgraduate education in Social Work. This can further contribute to ACP success. Finally, this training should include the use of mediation processes as a technique that helps and favours decision-making in the ACP process in a context of mutual exchange and dialogue [30].

\section{References}

1. Simon P, Tamayo MI, Esteban MS (2013) Advance Care Planning. Support guide for professionals, Seville, Spain: Ministry of Health and Social Welfare.

2. Romero CCM (1994) Law and bioethics before the limits of human life. Madrid, Spain: Ramon Arece Study Center.

3. Emaldi A (2005) Rights of patients in the Autonomous Community of La Rioja: special reference to the previous instructions, Spain: University of La Rioja.

4. Casado M (2007) New bioethics and law materials. Spain: Fontamara.

5. Bustamante CG (2013) Dysnnasia, therapeutic fury, therapeutic obstinacy. Clinical Update Magazine Investigates 32: 1643-1647.

6. (2002) Law 41/2002, of November 14, basic regulating patient autonomy and rights and obligations in the field of information and clinical documentation. Agencia Estatal Boletin Oficial del Estado, pp: 274

7. Jimenez JM (2018) Anticipatory Planning of Care in Primary Care: A Comparative Analysis from Social Work. Social Work and Health Magazine 89: 7-15.
8. Smith CR (1988) Social work with the dying and their family. Santa Cruz, Mexico: Editorial Pax Mexico.

9. Conde JAV (2003) The role of the social worker: psychosocial considerations for role innovation. The social worker's role: Psycho-social consideration for an innovation of the role. Social Work Notebooks (16): 7391.

10. Kramer BJ, Pacourek L, Hovland C (2003) Analysis of end-of-life content in social work textbooks. J Soci Work Edu 39(2): 299-320.

11. Morrison RS, Chichin E, Carter J, Burack O, Lantz M, et al. (2005) The effect of a social work intervention to enhance advance care planning documentation in the nursing home. J Am Geriatr Soc 53(2): 290-294.

12. Nedjat FR, Carrion IV, Gonzalez K, Bennett ED, et al. (2018) Exploring motivational interviewing to engage latinos in advance care planning: a community-based social work intervention. Am J Hosp Palliat Care 35(8): 1091-1098.

13. Black K (2005) Advance directive communication practices: social Workers' contributions to the interdisciplinary health care team. Social Work Health Care 40(3): 39-55.

14. Stein GL, Cagle JG, Christ GH (2017) Social work involvement in advance cares planning: findings from a large survey of socialworkers in hospice and palliative care settings. J Palliat Med 20(3): 253-259.

15. Peres J (2016) A time and place: the role of social workers in improving end-of-life care. J Soc Work End Life Palliat Care 12(3): 185-194.

16. Kwon SA, Kolomer S (2016) Advance care planning in South Korea: social work perspective. Social Work in Health Care 55(7): 545-558.

17. Francoeur RB, Burke N, Wilson AM (2016) The role of social workers in spiritual care to facilitate coping with chronic illness and self-determination in advance care planning. Social Work in Public Health 31(5): 453-466.

18. Arthur DP (2015) Social work practice with LGBT elders at end of life: developing practice evaluation and clinical skills through a cultural perspective. J Soc Work in End Life Palliat Care 11(2): 178-201.

19. Jimenez JMR (2015) Voluntad vital anticipada: la realidad sociosanitaria del Distrito Guadalquivir desde una perspectiva del trabajo social sanitario. Documentos de Trabajo Social 55: 223-240. 
20. Jimenez JMR, Farouk MA (2015) Knowledge, attitude and planning of the anti-ACPA vital will in the Guadalquivir health district of the province of Cordoba. General and Family Medicine 4(4): 114-118.

21. Kwon SA, Kolomer S, Alper J (2014) The attitudes of social work students toward end-of-life care planning. J Soc Work End Life Palliat Care 10(3): 240-256.

22. Gutheil IA, Heyman JC (2011) A social work perspective: attitudes toward end-of-life planning. Social Work in Health Care 50(10): 763-764.

23. Bomba PA, Morrissey MB, Leven DC (2011) Key role of social work in effective communication and conflict resolution process: medical orders for life-sustaining treatment (MOLST) program in New York and shared medical Care making at the end of life. J Soc Work End Life Palliat Care 7(1): 56-82.

24. Van RA, Scheyett A, Swanson JW, Swartz MS (2010) Psychiatric advance directives and social workers: an integrative review. National Association of Social Work 55(2) 157-167.
25. Baker ME (2000) Knowledge and attitudes of health care social workers regarding advance directives. Soci Work Health Care 32(2): 61-74.

26. Wang CW, Chan CLW, Chow AYM (2017) Social workers involvement in advance care planning: a systematic narrative review. BMC Palliat Care 17(1): 5.

27. Bern M, Gessert C, Forbes S (2001) The need to revise assumptions about the end of life: implications for social work practice. Health Soc Work 26(1): 38-48.

28. Arranz P, Barbero J, Barreto P, Bayes R (2005) Emotional intervention in palliative care. Model and Protocols, Spain: Ariel.

29. Auslander GK, Soskolne V, Stanger V, Ben SI, Kaplan G (2008) Discharge planning in acute care hospitals in Israel: services planned and levels of implementation and adequacy. Health Soc Work 3(33): 178-188.

30. Munuera PM (2016) Health mediation. Madrid, Spain: Tirant lo Blanch.

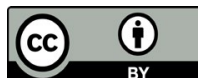

